\title{
Good Tidings: \\ Egypt's Election Hit and the \\ Multicultural Politics of Populist Nationalism*
}

\author{
Riham E.A. Debian ${ }^{* * *}$
}

\section{Introduction}

Without attention to the Eurocentric genealogy of multiculturalism, its tolerancefashioned neo-liberal leanings and its global flow and cultural transposition across local settings, multiculturalism becomes the 'paradigm power' regulating the edifice of the Anglo-American liberal democratic order. The structural inequalities of the latter are framed as "problems of intolerance, not as problems of inequality, exploitation, injustice" (Zizek 2007 par. 1). The solution is posed through a global surge in "tolerance talk" (Brown 2006 p. 2). Its design is to address multiculturalism as the "central problematic of liberal democratic citizenship" and fashion tolerance as "a post-political ersatz" and "a mode of late modern governability"(Zizek 2007 par. 2; Brown 2006 p. 2, 8). The ideological operation underpinning this fashioning lies in multiculturalism's neo-liberal disposition. The latter's bid to regulate "the presence of the Other both inside and outside the liberal democratic nation-state" is administered through the"culturalization of politics" (on the inside) and the "politicization of culture" (on the outside) with the designated outcome of turning tolerance into a depoliticized ideology and a management technique for circuiting deviance and co-opting difference (Brown 2006 p. 8; Zizek 2007 par. 1).

Tolerance thus emerges as the political end and ersatz citizenry stakes. It becomes the codeword for the mass cultural fun of enjoying the 'shopping mall boutique summa of the world's culture'. It becomes the catchword for the pleasure of consuming mass culture products and production of what Stam

\footnotetext{
* The idea of this paper was first presented under the title Boshret Kheir (Good Tidings): Egypt`s Transient Patriotic Hit and the Cultural Politics of Populist Authoritarianism" in Panel IV: Identity and National Revival: Cur ltural Expressions of Populist Politics (05 October 2016) at the international conference "A New Wave of Populism in Europe and the Arab World: Implications and Consequences for Civic Institutions". The conference was organized by the Arab-German Young Academy of Sciences and Humanities (AGYA) in Leipzig/Germany, 3-5 October 2016.

** Institute of Applied Linguistics and Translation, Faculty of Arts, Alexandria University.
} 
qualifies as "state-or corporate managed United-Colours-of Benetton pluralism" (Stam 1997, p.190). It above all sets in as the means for containing and exploiting the lure of the popular fun aesthetics of subcultures in a gesture politics of inclusion to boost the power paradigm of authority and sell democracy to the masses:

Multiculturalism without the critique of Eurocentricism runs the risk of being merely accretive - a shopping mall boutique summa of the world's culture - while the critique of Eurocentricism without multiculturalism runs the risk of simply inverting existing hierarchies rather than profoundly rethinking and unsettling them. (Stam 1997, p. 200)

In the Egyptian setting and in the case of the election hit song Boshret Kheir (2014), tolerance figures as the political logic for the transposition and resignification of multiculturalism in its dialogue with nationalism and populism - i.e. tolerating the masses' fun poetics to foster an anti-elitist national collectivity and project the image of democratic conversion before the world.

Similarly, Bayat points out the connection between discourse and authority in the following:

Any type of authority ... may be realized only within its own discursive paradigm ... the 'paradigm power' ... any challenge from without or departure from within this discursive space amounts to a challenge to those in authority ... fun ... represents a powerful rival archetype ... To maintain their authority, masters have to either modify their paradigmby enlarging it to embrace fun ethics ... or resort to curbing diversion. (2010, pp. 155157)

In light of the above, this paper, thus, deals with the transposition and resignification of tolerance-centric multiculturalism in Egypt's election hit Boshret Kheir (Good Tidings 2014). The paper particularly tackles the question of the expressive culture of contemporary nationalism, its repertoire with the global edifice of multiculturalism, and its cultural representation of a new paradigm of populist national identity - away from the elitism of ideology-based nationalism, within the technologies of violence of gendered nationalisms (McClintock 1997) and through the strategic deployment of the powerful powerless dimension of populism. Adopting a multicultural feminist perspective, the paper utilizes insights from cultural and feminist theories (Hall 1985, Stam 1997, Zizek 2007, McClintiock 1997, Joseph 1993.1994, Bayat 2010) to examine "Boshret Kheir"(2014)as a cultural artifact, whose context of production and consumption 
attests to the interrelation between the political and the cultural fields, calls attention to the "need for 'dialogic' and 'carnevelistique' theory of politics and popular culture" (Stam 1997 p.190) and highlights what Stam would qualify as the multicultural colonization of representation veiling the "power relations between the communities of the artifact" (1997 p.189).

The paper argues for the song's representation of the multicultural politics of populist nationalism, whose expressions transpose the opposition between multiculturalism and nationalism onto the terrain of tolerance, repackage nationalism through the populist fun aesthetics and politics and rebrand the gender politics of both populism and nationalism via the corporate management policies of neo-liberal capitalism. In its non-statist production and outlook (in a break from the tradition of post-independent national singing), the song suggests a neo-liberal model for expression and management of populist nationalism that deconstruct the long-entrenched dichotomization of neo-liberalism and populism, gendered nationalism and authoritarian consolidation: "neoliberalism's valorization of the 'free market' by way of an ostensibly anti-statist outlook" (Bruff 2012, p. 107-8). Boshret Kheir (2014) configures the shaky nexus through its corporate cultural politics of representation, repertoire with the maculinized political culture of the nation-state and their effect on both marketing the popular rhetoric of formal politics and naturalizing the gendered politics of populist nationalism. The paper conducts the analysis along three axes. The first axis examines of the discursive process and construction of gendered designated identity of the Egyptian nationals-geared towards amassing popular support for the voting process and reducing democracy to an electoral premise in accordance to the stakes of the power centers (neo-liberal practices and militarized authoritarianism) governing the Egyptian setting. The second axis inspects the song's audiovisuals and their effect on projecting an image of national collectivity within the depoliticized neo-liberal multiculturehoned to populist and popular imaginings and tethered to the populace's informal fun poetics. The third axis poses an open query about the neo-singers of the nation-state and its implication with respect to both Egypt's location within the regional and international political economy and the end of nationalism/authoritarianism as 'we know it'.'

Boshret Kheir (2014) was produced in the aftermath of the second wave of Egyptian Spring (garnering a Western furor regarding its labelling - revolution, 'coup', democratic coup or 'popular coup') and against the backdrop of a global backlash with respect to Egyptian 'exceptionalist' impregnability to democracy. Time magazine cover (Vol. 182, no.4) featured Egyptians in terms of the "World's Best Protestors, World's Worst Democrats" in implicit invocation of the Eurocentric thesis of Arab exceptionalism (Debian 2015). The song's 
message, a response to and ironically through the Anglo-American packaged power-paradigm, was a call for a massive turn over to the polls in vindication of the upcoming election process that is destined to materialize the translation of Egypt's laid out road-map to democracy. Its production management technique was tolerance-manufactured multiculturalism. Transposed to the Egyptian setting, it was re-signified in accordance to the national moment with its fear for and furor over the true nature of Egyptian identity and in tune with the political end of election. The re-signification came in through the simple thematic of the joy of life and the joyful everyday practices of the populace's popular fun culture. The populace was thence joyfully enlisted to fend for national identity and combat the threat of 'anti-fun-dementalism' (Bayat 2010, p.153) posited by Muslim Brothers' short-term rule. The prescribed means was through their jubilant assertion of recognized existence and voice before the world - as befitting their designed and designated gendered agency to a nation-state in the throes of patronizing neo-liberal capitalist world order.

To that end, its writer, Ayman Bahgat Qamar, wrote its lyrics in Colloquial slang Arabic - in deviation from the traditional mode of national singing. Its composer, Amr Mostafa (infamous for his conspiratorial take on the Arab Spring and the unrelenting advocacy of Mubarak's paternalistic/patriarchal regime) uses the jubilant hard-rugged beats of Cairo street music with a melancholic schmaltzy prelude. The song is audibly delivered through the exotically husky voice of a non-Egyptian Emirate singer, Hussain al-Jassmi, to be video clipped by director Hisham Fathy and produced by corporate T.V station CBC with the visuals -adaptation of Pharrell Williams' global hit Happy- localized to the Egyptian setting.

The result is a corporate election song and virtual-turned-national hit (receiving 1million views upon its launch and 155 thus far), whose multicultural design ironically boosts the paradigm power through the self-defeating pursuit of exiting its discursive space. This is done through tethering politics and poetics to popular expression, populist experience and local-global culture in tacit cooptation of former's subversive potential and in line with the commodifying strain the latter. The outcome is a cultural artifact, whose venture into the corporate managed political field (and mix of disparate elements) showcases the accretive packaging thrust of depolitized multiculturalism (Stam 1997), the 'culturalization of politics' and 'politicization of culture' qualifying liberal multiculturalist ideological operation (Zizek 2007) and the nexus between corporate policies, multicultural politics and the gendering impetus of populist nationalism. The ultimate after effect is Boshret Kheir (2014) — the popular national song articulated in the new nationalist language of the corporate managed multicultural nation. The latter's simulation of 'life as politics' (Bayat 
2010) revamps patriotic sentiments and exits the paradigm power to paradoxically deflate the resistant potential of life's politics of fun and subverts traditional authority - departing from and configuring its discursive space along the intersecting interests of the multiple power-centers governing the post-Arab Spring Egyptian setting.

\section{Culturalization of Politics: Boshret Kheir and Tolerance as Marketing Design}

In his critique of the post-political liberal project of knowledge production, Zizek (2007) identifies the "culturalization of politics" as "the liberal multiculturalist's basic ideological operation" (par 1). Culturalization of politics operates through what Hall ([1973] 1980) would qualify as encoding ${ }^{2}$ of the political through the story of cultural with tolerance as the discursive form for the mediation of the political field. Accordingly, political problems of inequality, economic exploitation and injustice are encoded in the story of cultural difference that is decoded and communicated along tolerance and intolerance binary-depoliticized and neutralized in tune with the neo-liberal multiculture. Thus, tolerance becomes both the politically-correct ideological smokescreen of the "retreat and failure from direct political solutions" and the smoke signal for the turn from the "culturalization of politics to the politicization of culture"designed to evade discussions of emancipation and political struggle (Zizek 2007, par 2). In Boshret Kheir (2014), this encoding of the story of tolerance designed to communicate the meaning of the nascent democratic exercise to the Egyptian populace - is enacted through the language and the visuals.

The language of Boshret Kheir (2014) is structured away from the abstracted symbolism of traditional nationalist singings. Written in a standard colloquial (ammiyyat al-umiyyin in Badawi's typology), the song uses the everyday language of the masses. ${ }^{3}$ This linguistic choice - not a normative preference of nationalist aesthetic practice - constitutes a break from the elevated phraseology of traditional patriotic singing; the latter's conceptual parameter was hung on nation-ness, sacrifice and personality cult. It also institutes a shift towards a gesture democratic politics of inclusion, where the populace's lexicon becomes the vehicle for enunciation of the new conception of belonging and nationality. Moreover, this choice simultaneously encodes a reversal of both the linguistic hierarchy of national language varieties along with the top-bottom approach of envisioning the societal wellbeing and enacts a reversal of the militarized postindependent unity - "a unity that is synonymous with anonymity" (Thomas 1997 , p. 75). The effect is strategically paying homage to the multiplicity of masculine individual and individualized cultures of Egyptian nationhood recognizing difference and diversity that is tied to the electoral map and voting 
machinery. Ultimately, the song's enunciation structure and language choice purport a shift to a new regulating parameter of the populist nationalism of the multicultural national collectivity, the terms of which is related through patriarchal idiomatic kinship (Joseph 1993). The latter coerces diversity into a brotherhood paradigm that is functionally designed to propagate massive turn outs of the structured as connective ${ }^{4}$ collectivity of male Egyptians. Male Egyptians figures as the rightful claimants of national polity and the indispensable cogs for the functioning of the voting machinery.

\subsection{Patriarchal Idiomatic Kinship and Multicultural Nationalism}

Divided into three stanzas, the song begins with incentivizing Egyptians to take the step forward and vote. Juxtaposing effeminate silence with maculinized speech, the first stanza laments the past passivism that has robbed Egyptians of their manly status as the fenders of Egypt, who are capableof writing the future on their own terms and thereby dazzling the world into recognition of their august presence. The second stanza builds on the initial setting of masculine bravado through a sketchy chart of the political geography of the Egyptian voting map. Enumerating the regional or rather provincial identity politics of each locale, the stanza charts a personalized geography of the Egyptian setting through strategic employment of سم النسب (ism alnasab is a personal noun that defines the subject's identity via ascription to a place of origin) that names each constituency after its local habitats: 'biheri', 'monoufy', 'demiati',' iskandarany', 'saedy', 'sohagy', 'qenawy', sawaysah' ... etc. This provincial politics of naming at once mobilizes tribal sentiment and projects a pluralistic image of Egypt's upcoming politics transposing the provincial onto national belonging, while back-staging the problematics of urban inequitable development and disenfranchisement rending Egyptian political geography. More specifically, this ploy to provincial politics discursively constructs a panorama of multiplicity and diversity to translate the multicultural politics of the new nation onto the Egyptian humanized geography acknowledging the individuality of the multifarious communal cultural identities to simultaneously enlist their collective agency and veil their unequal enfranchisement. The third stanza comes to foster this celebratory homage to multicultural populist nationalism, with its affected construction of tenuous heterogeneity-cum-collectivity underpinned by tribalism and provincialism, through maculinized brotherhood rhetoric and idiomatic kinship. The latter regulates the different provincial differences and border zones in accordance to their geographical distance from the center. Not only is this "gathering a gathering of men" according to the song wording, but also"الصعيدى" (El-Sei'dy: the resident of upper Egypt) is brought in conjunction with "البورسعيدى" (the resident of the Suez Canal city of Port said) and is given 
the epithet "بحيرى منوفى و دمباطى دول اقرب ليا من اخواتى" (brother's son). "ابن اخوه) (Biheri, Monoufy and Demietti are more kin than brothers), whereas حلايب(the Halayeb triangle referencing a place not people) are "نل وأرايب (folks and cousins) and "ناس مطروح" the people of Matrouhare given a "heartfelt welcome". Halayeb Triangle and Matrouh are two border zones, whose distance from the national center warrants a parallel kinship distance. The effect is a simplistic account of the social geography of patriarchal kinship relations between the northern, southern and border regions of the Egyptian nation-state. Despite its discursive design and particularly through its marketing politics, this sutured social geography encodes a story of national bonding and belonging away from the anonymity of nationalist articulation, and within the multiculture of current world order. The latter's tolerance-centric ethos linguistically reproduces the inequitable enfranchisement of the communities behind the artifact to project a tenuous heterogeneous collectivity that tolerates differences and injustices to uphold the new nation. The ultimate effect is forging a new language for both the neo-liberal nation and its newly forged multicultural nationals-designed to forge designated national agency.

\subsection{Neo-Nation's Language and Gendered Designated Agency}

Indeed, it is particularly through this new language that the shakiness of the linguistically forged multicultural nationals is covered up (if not redeemed) and national belonging is transposed onto a design for their gendered designated agency. Qualifying the register and language level of his previous song "تمرد (Tamarad: Arabic verb for rebel), Qamr uses simpler wordings that reference direct material actions - "قوم"اعدلها" ,"خد عهدا", "قوم نادى" ("rise up", "take an oath", "put to right", "say before the world") — with the use of imperative indexing urgency and necessity and enlisting a sense of agency and duty. Abstracted concepts like dignity honor, nationhood and nationality are avoided with the traditional gendering of nationalist symbolism allocated to the first stanza-Egypt is mentioned once with its personified effeminized presence structured as the backdrop and incentive for the action sought implementing. The anonymity of national unity is subverted through alternately adjusting the register to the dialects of the diverse geographic and ethnic provinces of Egyptians' cultural identities_ - "مرحب" ("marhab", a greeting word used in the Western border) is used in connection with Matrouh. Each province is referenced with idiomatic description-- "الاسمعلوية باما كادو العدا" ('Ismalawiyah yama kado al-aada': people of Ismailia who teased the enemies). The gesture politics of solidarity through difference and diversity is structured among the multifarious constituencies constituting the patriarchal nation. 
The message is clear: this gathering is manly, vote to actualize your patriarchal connectivity and control your destiny through fending (or rather as fenders) of Egypt's national identity and unity-before a world order adamant on framing reality on its own term. Such tactful recognition of difference and diversity, underpinned by strategic deployment of idiomatic patriarchal kinship, purports national agency that is premised on the gendering of both Egypt and Egyptians. Building on the initial gendering of silence versus speech, the simplistic wordings discursively invert the care/control terms of the patriarchal kin contract entrusting the care to the populace, who are enticed into a transaction where their response for Egypt immanent crisis would garner their control of Egypt and their destiny. Egypt figures as the damsel in distress in need of saving. Her redemption is the nationals' votes and their specified function and benefit to a polity in the throes of legitimization crisis. As such, their national agency falls into what McClintock (1997) qualifies as gendered designated agency - " agency by invitation ... bereft of historical motivation ... [driven by] the structural necessity of war" (McClintock 1997, p.98). Driven by the structural necessity of legitimizing Egypt's road-map to democracy, the agency charted in the song is the gendered designated agency of the neo-liberal nationals-designed to simultaneously posit the urgency of fending national unity against an external enemy and construct their massive turn-out as national defense and security measures. This subtle bravado gendered construction is further enhanced by the audiovisuals. The latter's ploy to popular poetics paradoxically politicizes the fun culture of the street music to co-opt its dissent thrust and thereby parodying and culturalizing the fun of 'life as politics' (Bayat 2010).

\subsection{Cutting the edge of 'life as politics': Audio-Visuals and Populist Singing/Imaging}

In clear break from the enthralling enthusiasm of the sixties, the earnest formalistic celebratory tonalities of the seventies and eighties and in obvious distinction from the schmaltzy contemporary patriotic singing, the song video steers away from being prescriptive and peremptory through a tactful deployment of mahraganat 5 (translates as "festivities") street art performance. Building on their increasing popularity, Boshret Kheir emulates the mahraganat songs' complex, fast-and-furious rhythms, rhymes, word-play and hip-hop tuning. Opening on a poignant melancholic tone, the song breaks into explosive disco-ish jingle with the movement from silence into action of the lyrics translated and audibly incarnated through the abrupt acceleration in tempo of the tunes and what writer Youssef Rakha (2012) qualifies as "sudden shift from deep poignancy to explosive silliness" (Rakha 2012, par 2). In fact, it is particularly 
this explosive silliness and fun aesthetics that enables the song to instantiate the story of tolerance underpinning the "culturalization of politics"(Zizek2007) through what Bayat's identifies as "the art of presence ... in the life of nonmovements, in life as politics" (Bayat2010, p. 26).

Perfecting the packaging of tolerance, the audio-visuals capitalizes on the lure of what Bayat ${ }^{6}$ (2010) would qualify as "the politics of presence" of mahraganat youth's aesthetics, whose "normative subversion" figures as the new vehicle for imaging and singing the nation (Bayat 2010, p.128). First, complementing the tribal and provincial sentiment invocation of the lyrics, the song's music administers a parallel invocation of the excluded urban spaces and cultures of al-ashwayat (Cairo self-developed or rather 'underdeveloped' communities). The anti-elitist aesthetics of mahraganat singing is strategically deployed to institute a gesture politics of inclusion. The latter accommodates the marginalized street music (consumed by the masses but not recognized as proper art form in the institutionalized cultural milieu) to project democratic veneer and pluralistic politics that ultimately sell the voting process (product) to the disenfranchised masses. Second, in its tactful reversal of the binaries of center/margin, high/low and mainstream/popular, the song's mahraganat-like music administers a tacit co-optation of the street music dissent-fun politics. An off-shoot of the statist hand-off policies towards urban planning, mahraganat aesthetics is an expression of the location from which it emanates where urban disenfranchisement and under-development bring forth self-regulating communities residing in congested spaces and deprived of essential services. These communities are forced to make do with communal tactics of survival, whose inadequacy furnishes the subtext of mahraganat songs that at once makes life fun and makes fun of life. Such fun politics or rather making fun of formal politics becomes the survival strategy and the dissent politics giving vent to the embroiled anger of disenfranchised youth. Third, in further co-optation of its dissent politics, the deployment of mahraganat issues the corporatization of the popular and populist thrust of mahraganat transposing the communal selfregulated underpinning of its production onto the politics of mass produced culture; mahraganat are communally financed through the collective effort of a group of youth, who makes جمعية (gamiaa: cooperative for collecting money) to finance and produce the song (costing average of 1000 to 3000 L.E). The song is then uploaded on YouTube to garners views, according to whose number the dream of fame and social upward mobility is liable to be realized (Interview with Kilany, 2016). ${ }^{7}$ Fourth, this strategic utilization and cutting of the oppositional edge of popular poetics sets a vexed relation between the state, its monopoly on the national and corporate politics. The latter institutes (borrowing Bayat's) 'a departure from within the power-paradigm' that sets the tune for the multicultural 
imaging and singing of the neo-liberal nation publicizing the underground and marginalized aesthetics to standardize its populist lure and thereby parodies both its fun policies and formal nationalist politics. This is done in reversal of Bayat's thesis of the libratory thrust of 'life as politics' and in successful ploy to regulate and deviate the dissent politics and poetics of mahraganat. Ultimately, the scatting rhythmic tunes of Boshret Kheir vexes the authenticity claims of formal nationalist singing and politics - with its underlying homogeneity ethos designed to monitor the border trespass of cultural identity boundaries - through a new nexus for the multicultural populist national image-nation that synthesizes the tribal provincial with the urban local to be wrapped in the global. The result is a neo-liberal nationalist pack - best encapsulated in the visuals.

\subsection{Visuals and the New Nexus of the Neo-Liberal Nationalist Image- nation}

In its logic, the visuals seal the culturalization of politics and its underpinned gesture politics of inclusion further confounding the 'national' through a politicized adaptation of Pharrell Williams' hit song "Happy" (2013). Mimicking "Happy" (2013), Dir. Hindy adjusts the global hit's visual grammar to the domestic Egyptian setting localizing its imagery to the election context and politicizing its universal thematic to tune up with the unfolding neo-liberal democratic machinery. The camera opens on a wide angle long shot capturing a marine landscape rimmed with iconic architectural structure and cultural artifact (min. 0.05). People then make their appearance (min. 0.06) with banners transcribing the material action wording of the song: "انزل, شارك ,حتعدلها, حتعملها بشرة, مصر خير , صوت ("you can do it", "can put in order", "participate", "go and vote", "good tidings"). The camera then bursts into explosive kaleidoscopic movements capturing a phantasmagoria of images seething with Egyptians from diverse locations and different walks of life. Pictured in all their various looks, dress codes and environments, Egyptians are captured boogieing and bopping to the abruptly accelerated tempo of the tunes and smilingly waving as they bear signs of 'vote', 'participate' and the names of the geographic and ethnic provinces they hail from.

This adjustment not just issues a culturalization and domestication of a global artifact and aesthetics to local setting harnessing its utility to the immediate political context. It also institutes a parallel adjustment of global icons to localized pattern of consumption. The mix between human and cartoon figures in Happy (2013) is replicated and configured in accordance to the Egyptians' pattern of consumption with the Minions replaced with Sponge Bob and Dora (2:20) - given the latter's wide viewership by virtue of the dubbed versions infiltrating the Egyptian market. More importantly, this culturalization 
administers a comparable usurpation of Happy and mahraganat's low-budget publicizing tactic utilizing their Web 2 technology-based pattern of dissemination to appropriate its popular lure and capitalize on its populist thrust. Like Happy and mahraganat song, Boshret Kheir was launched on You Tube (16 May 2014) prior to its release on the silver screen of a privately owned channel, $\mathrm{CBC}$ - the latter funded the production and holds the rights to the song. Ultimately, the visuals showcase a new mechanism for national imaging and singing. This new mechanism operates through the following: first, attention to the nexus between the provincial, local and global; second, utilization of populist expression, popular social media resources and youth imagery and icons to set up a token recognition of plurality without pinning it down to material aspiration and enfranchisement. Third, it sets in a commercialized promise of happiness for all through a simplistic and childlike content message (a pseudo- United-Colour of Benetton diversity and a Mobinil like-ads-content message). This not only made the song an easy-to be-bought political commodity, ${ }^{8}$ it also enabled the marketing of the gendered designated agency covering up the logic of power, its context-specific dealings and its design for infantilizing the populace into buying into a polling commodity.

Ironically, or rather specifically due to its well-wrought design and well thought medial movement (from You tube to the Silver screen), Boshret Kheir became an anchor for vernacularized imaging of highly individualistic conflicting contested visions of national identities . In fact, it is particularly due to its deviationfrom the 'discursive space' of 'power paradigm' and gesture 'departure from within' that discursive space that the song set into action what Fiske (1989) and Bayat (2010) respectively posit as the paradoxical effect of the repertoire between mass and popular culture and the self-defeating pursuit of harnessing the youth politics of fun to sell the "anti-fun-damentalism" of authority-centric formal politics (Bayat 2010, p. 153). The repertoire between mass and popular culture, embodying both "forces of domination and the opportunities to oppose and evade them from the subordinated" (Fiske 1989, p.25), enabled the ironic spreading and checking of the popular lure of Boshret Kheir through mass consumptive reproduction. Literarily every Tom, Dick and Harry engaged in Web 2 technology driven remakes of the jubilant audio-visuals took the occasion to translate its content and tempo according to their own terms. The strategic deployment of the youth fun politics subverted the iconic political stature of nationalist singing. People's remakes were filled with ordinary and mundane visuals in a typical fashion of what Bayat identifies as the "tacit encroachment of the ordinary" ((2010, p. 10). This sets in (qualifying Zizek's dictum) the politicization of the personal and personalization of the political paradoxically making politics fun and making fun of formal politics. The effect 
is a new paradigm for national imagining where neo-liberal democratic imaging becomes (configuring William's phrase) 'multiple rooms without a roof' multiple multiple rooms with corporate managed glass ceiling.

\section{Multiple Rooms with Corporate Glass Ceiling: the New Singers of the Nation}

Corporately induced and managed, the subversive after effect of Boshret Kheir released a plethora of fun poetics, whose wide range (from overt dissent and ridicule to outright applause and celebration) provides for a tactile reflection of the ambiguous setting in the post-election landscape. This ambiguity, catalyzed by social media tacit re-charting of the media landscape, puts the state into an ever-deepening legitimization crisis with little possibility for tethering the multiplicity of national imaginings into a unanimous and uni-centric formula and little potential for the solidification of personality cult soaring above accountability. In a televised national address (August 2014), president El-Sisi states: 《الزعيم الر احل جمال عبدالناصر كان محظوظ، لأنه كان بيتكلم والإعلام كان معان (The late leader Abdel Nasser was lucky; whenever he talked, the media was with him) (Abbas 2014 par 1).

Half right in that regard, Nasser's fortune was not due to the unanimous backing of state-owned media apparatus that magnified his leadership stature and personality cult aura. It was rather due to the absence of both digital communication technologies and corporate media. On the one hand, digital technology brings down the walls barring communication to bring about a multicentric media order. In such order, the nation-state's policies are debated through multiple chat rooms contesting the unanimity of national unity and enabling the transience of uni-centric and personality cult driven vision of Egyptian national identity. On the other hand, corporate media capitalizes on the popularity of social media and its semblance of plurality to contain its de-centered multiplicity setting a glass ceiling regulating its potential dissent politics and composing neoliberal statist tunes for singing the nation. This brings a question about the singer/singers of the nation and its implication with respect to the shape of populism and nationalism in today's' Egypt. This question is best answered through the neo-liberal politics underpinning the production and dissemination of Boshret Kheir.

Against the mainstream practice of state-T.V. production of national songs, the song is produced by CBC, a privately-owned satellite channel famed for its endorsement of neo-liberal capitalist policies, unrelenting advocate of gulfEgyptian brotherhood and support of the military establishment. Against the classical practice of singing the nation, Boshret Kheir is sung by an Emirate singer Hussein al-Jassmi, who does not appear on screen, yet becomes the Voice 
of the new nation instructing Egyptians on the benefits and necessity of voting; al-Jassmi's citizenship is based on a no-vote pact. The song capitalizes on the global success of Williams' "Happy" (2013), whose production-release date and mechanism of dissemination echo that of its replica Boshret Kheir with the latter's release first on You Tube before its launch on the silver screen. The song viral reception and wide-ranging remakes - fostered by the butterfly pattern of consumption of Web 2 technologies - enable the production of parodies. The latter, though divested off overt oppositional politics, disables the permanence of unanimous iconization of leadership stature and personality idolization.

Unlike the statist nationalism of the previous century, Boshret Kheir's singing, imaging and reproduction mechanisms attest to the evolution of new paradigm for populist nationalism where neo-liberal market forces interject with statist politics reproducing its nationalist poetics through a multicultural ethos and populist aesthetics. The latter injects the provincial, local and global within the patriarchal kinship structure qualifying the previous patriarchal statist outlook through shifting the focus of national identity and unity to the populace. The populace is granted a redemptive agency - bracketed by invitation and functionality of presence and salvaged by maculinized ethos and idiomatic kinship. The outcome is the glass ceiling of neo-liberal nationalist grid that markets multicultural populist nationalism to shift the gear away from statist authoritarianism while reproducing and re-articulating its paradigm in accordance to the congruence or conflicting stakes with the state. The news coverage of Egyptian maritime borders dispute with the KSA poses as a discoursal indicator of the complex relation and repertoire between the neoliberal market-centric actors of the present-day nationalism and the state. The latter's legitimization crisis discursively sanctioned and managed by non-state actors through falling back on idiomatic patriarchal kinship. ${ }^{9}$

\section{Conclusion}

This paper tackled the question of cultural representation of populist national identity in the election hit "Boshret Kheir" (2014). The paper examined the hit song's wordings, audio-visuals and their repertoire with popular culture and the political context of enunciation. The paper reached the following findings. First is the re-signification of multiculturalism in the Egyptian setting. Against the depoliticized theorization underpinning the academic enunciation of the present day multiculture, the song showcases the politicization of the muliculture through strategic transposition of its tolerance ideological operation in the Egyptian setting politicizing the Egyptians' cultural differences and diversities to propagate its promotional call for election. Second is the multicultural politics of populist national identity construction. The transposition of multiculturalism 
in the Egyptian setting and its tactile politicization of culture to sell politics issue a new logic for populist national identity construction and agency. This new logic undercuts the taken-for-granted statist authority of the previous century through the active involvement and manipulation of neo-liberal market-centric players. The latter strategically deploys the popular social media, the populist youth aesthetics and expressions to construct an image of solidarity tethered to populist imaging and imagining, and pinned down to the interests of multicentric power regimes. Third is the gender politics of multicultural populist nationalism. Selling politics through culture, the political logic for populist nationalist identity replicates the technologies of violence of nationalism through both the gender symbolism of Egypt as a women and the functional agency of the Egyptians - designated and bracketed by their functionality to the election event. Gender politics thus function as the redemptive logic for gendering the national agency and building a brotherhood-furnished collectivity. The final finding is the instrumental employment of fun poetics and its bearing on selling populist nationalism, consolidation of what Bruff (2012) terms neo-liberal authoritarianism and the anti-fun-dementalism of authority solidification. The song's success story (and still to an extent spirited afterlife) highlights the significance of the anti-elitist fun poetics in the logic of populist nationalism and its closure in authority consolidation - to the foreclosure of life as politics, and as a safety valve for the political. Against Boshret Kheir, al-Jassmi's second election song "Masa al-Kheir ya Ra 'is" ("Good Afternoon President 2018) fell short before Hakim's election song "Aandak Nizoula" ("You have an Errand" 2018). Unlike al-Jassmi's (2018), Hakim's video-clipped song (2018) does not feature any celebrity actors rather ordinary people dancing in the streets with the people as the main addressees - spoken to and of within their anti-elitist fun politics and through the masculinzed discourse of national identity.

\section{Endnotes}

${ }^{1}$ Nationalism in the post-independent state of the previous century was avangardist or
in McClintock's terms, borrowing Said and Eagleton "anticipatory ...grabs instinctively
for the future, projecting itself by an act of will and imagination beyond the
compromised structure of the present" (McClintock 1996 p.196). As such, its rhetoric
was more elevated clocking difference in collectivity veneered with a spirit of inclusion
and sophistication with careful attention to the political correctness of language.
Contemporary protectionist populism is past-oriented designed to reclaim past glory
through populist rhetoric. President El Sisi's campaign slogan " " "Long
Live Egypt"), echoing Trump's "Make America Great Again", articulates the same 
rhetoric and orientation with the life of Egypt predicated on the dis-life of disenfranchised Egyptians and the reclaiming of America's past glory hinged on making it whiteagain. After all the failure of Clinton was forecasted by the popularity of the comedy drama web television series Orange is the New Black - hence the inevitability of White.

${ }^{2}$ In "Encoding and Decoding in Television Discourse" (1980), Hall argues against the linearity of traditional model of mass communication research. Hall calls attention to the different moments of production, circulation and distribution as a complex structure of relations that contributes to the communication of the discursive form in which the television discourse takes place. Hall's argument is for recognition of the privileged position of the discursive form in the communication exchange and attuned attention to the interface between the social practice and discursive structure. The latter enables the encoding of historical event into communicative event through the story-form the event might take. As Hall states: " the event must become a 'story' before it can become a communicative event" (Hall par 1).

3 According to Elgibaili (1996), low variety of colloquial Arabic, used by the uneducated, has been strategically deployed in political speech to affect solidarity with the masses.

${ }^{4}$ In her fieldwork on the psycho-dynamics of Arab patriarchy in the Lebanese context $(1993,1994)$, Joseph identifies the kin-contract as the regulating ethos of Arab patriarchy (in distinction from the sexual contract of Western patriarchy). According to Joseph, this Arab-specific kin-contract operates through four set of psycho-social dynamics that set the individuation of Arab selves, namely connectivity, kinship patriarchy and idiomatic kinship. First, connectivity is "an activity or intention, not a state of being...[whereby] women and men, juniors and seniors, equally engaged and interwoven in webs of relationality...[signaling] maturity partly by the successful engagement in a multiplicity of connective relationships across gender and age groups, with kin and non kin" (Joseph "Gender and Relationality" 467). Second, indirection involves "communication ... often indirect ... conveyed by circumlocution or through statement to third parties" (Frontier 18). Third, kinship patriarchy is gender and age marked where gender-relations and roles are predicated on the interdependence of care/control (love tempering the imbalance of power). Fourth is the idiomatic kinship in which the boundaries between domestic/public arenas are shifted and in some instances effaced with kinship idioms and morality flowing into public life so that "nonkin persons could evoke the legitimacy and expectation of kin relationships in political, economic and social spheres" through the cultural legitimacy of the language of kinship. (Gender and Relationality 468)

${ }^{5}$ Music critics identifies two sources for the origin of Mahraganat: first, the traditional mystical melodies of the mould singing or Islamic festivals that feature rhythmic music and mystical poetry; second, the earlier generation of youth music, known as Shaabi, roughly translated as popular, originating in the 1970s with working class musicians starting their production of their own soundtracks. Shaabi singers were in part inspired by mould singing, which they turned into raspy voiced songs about the common people 
infused by Egyptian humor. Originating in Salam city (in Cairo suburbs), Mahraganat stayed largely in Salam City and the surrounding suburbs until 2011, when the overthrow of Hosni Mubarak brought its artists greater exposure. A prominent mahraganat singer, Sadat released a series of songs over the internet dealing directly with politics - "The People and the Government" and "The People Demand Five Pounds of Phone-Credit" (a riff on the revolutionary popular chant "People Demands a Regime Change"). Yet, mahraganat artists resent the oft-made suggestion that their art is born of the revolution. They started making music long before Mubarak fell, which does not deal with national politics, particularly because the latter often ignores the basic needs of struggling communities. Many of the Mahraganat singers are opposed to political Islam and the Muslim Brotherhood, because hard-line conservatives see music as sinful, though mahraganat is equally criticized by the less conservative. An offshoot of the burgeoning informal communities of el-ashwaiyat, mahraganat songs articulates the dire realities of governmental negligence to the people that leads the youth to evade the quagmire realities of the real world through drugs, sex, singing and dancing. Indeed, as an embodiment of what Fiske identifies as the evasive pleasure of pop-culture, mahraganat celebrates the fun politics of libidinal pleasures of their subculture and status in society. This celebratory articulation not only shames society and government by their negligence, but also shocks mainstream society and politicians into recognizing their social and political presence and claims - especially that mahraganat has infiltrated the Egyptian cultural scene. Like "Boshret Kheir", mahraganat songs steer away from politics - only a few songs are explicitly political-since as Sadat states: "this is not what most people like ... Most people want to have fun, so our most popular songs are humorous" (qtd. El Nabawi par 5).

${ }^{6}$ According to Bayat (2010), the art of the presence is the mode of political practice of youth. The latter are social agent of change in the Middle East by their unconventional practice of life-as-politics where the politics of presence and assertion of right carve out spaces and places from the power paradigm and change the practice of authoritarian politics through practice, not protest. For Bayat, the art of the presence is closely related to the non-movement nature of youth action. Unlike conventional social movement, non-movements are not organized challenges with articulated ideology or recognized leadership. Their practice of politics revolves around 'practice', not protest, and is characterized by collective consciousness of non-collective actors. The latter are self identified by visible markers of life-style and ways of doing things. Their everyday practice and presence effects normative subversion and dissent that takes away from the power paradigm and changes its exclusive monopoly on public space. Bayat cites mahraganat among the youth practice of dissent politics where fun - the terrain of the political practice of non-movement youth culture - becomes a means for assertion of presence and invasion of public spaces against power-paradigm disenfranchisement and marginalization.

${ }^{7}$ In a personal interview conducted with an insider to the mahraganat world, Ibrahim al-Kilany, a 28 years old taxi driver and Alexandrian mahraganat producer, explained the working of the business and how he has entered into that world. His story with 
mahraganat started with wedding parties, when he and his friends alternately were giving each other wedding presents in the form of production of a song where the groom's name is mentioned. The wedding present or نقوت (noqout is a a customary act of complementing where an amount of money is given to the person who has a celebration be returned or repaid to the person who gave the money whenever s/he has a happy event) are regulated through the structure of gamiaa, where an informal contract are written between the parties involved to save each's right for the amount of money contributed. This money is given to song writers, composers and street dancer and a song is produced in the wedding with the name of each money contributor mentioned, which gives acknowledgment, recognition and fame to each one amid his community and in his district. The singer then would use the song produced and start on marketing his product through networking - normally conducted via Tok Tok drivers and on YouTube. When the song proves a hit, the singer then would promote it further through the mahraganat private channels. The latter would publicize the song according to the number of hits it garners on YouTube and the intensity of its reception with the masses. On asking Kilany about copyright issues, he answered that normally the singer would ask their permission and they would normally grant it, since everyone has taken their bid - the groom and the friends got fame and recognition in their district. If the song proves a T.V. hit, the recognition would reach the silver screen. The money is not the issue.

${ }^{8}$ The song proved a smash hit. During and in the aftermath of the election, it was widely played on wedding ceremonies, voting polls, coffee shops and shopping malls. As befitting its popular media of dissemination, it has triggered a butterfly chain of myriad remakes with the jingles adapted to highly individualized imaging of Egyptians (from different walks of life and social settings) dancing to the tunes, personalizing its imagery to momentous events in their lives and invoking its iconic political stature to produce an image of (commercialized and packaged) solidarity and dissent that cuts across various spectrum. The last of these remakes is Peace Cake Production's ELECTION RESULTS! - "Boshret Kheir" American version launched on Face book (17 November 2016) upon Trump's announced win.

${ }^{9}$ The framing of Tiran and Sanafir border dispute was administered through the privately run media channels - mostly financed by a mix of Egyptian and Gulf based money. Its discourse management fell back on idiomatic kinship discourse markers rationalizing the government unilateral decision on the grounds of the brotherly relation between the two states (بين الاتشقاء) and in terms of the just historical rights that is unlikely to jeopardize Egyptian interests, since 'it is the house' - in colloquialArabic (في بيتها). 


\section{Work Cited}

Abbas, M. (2014). "السيسى: عبد الناصر كان محظوظ" (El-Sisi: Abdel Nasser Was Lucky) Al-Masry Al-Youm. 05-08-2014 12:32. Last Retrieved from http://www.almasryalyoum.com. June 2017.

Al-Jassmi, Hussein (2014). "Boshret Kheir". Last Retrieved from https://www.youtube.com May 2017

---- (2018). “Masaa al-Kheir.” Last Retrieved from https://www.youtube.com June 2018

Bayat, A. (2010). Life as Politics: How Ordinary People Change the Middle East. Amsterdam: Amsterdam University Press. Last Retrieved from https://openaccess.leidenuniv June 2017.

Brown, W. (2006). Regulating Aversion: Tolerance in the Age of Identity and Empire. Princeton: Princeton University Press.

Bruff, I. (2012) "Authoritarian Neo-liberalism: the Occupy Movements and IPE." Last Retrieved from https://www.tandfonline.com

Debian, R. (2015). "Egypt's Translating Democracy: A Model in the Making." Alexandria: Journal of the Faculty of Commerce For Scientific Research, Jan 2015, vol. 52. No 1.

Elgibali, A. (1996). Understanding Arabic: Essays in contemporary Arabic Linguistics. Cairo: the American University Press in Cairo.

Fiske, J. (1989). Understanding Popular Culture. London \&New York: Routledge. Last Retrieved from http:// seminariocultura.sociales.uba. June 2017.

Galanopoulos, A. De Cleen, B (2016). "Populism, Nationalism and Transnationalism." Green European Journal. Last Retrieved http://greeneuropeanjournal.eu. June 2018

Gloria, M. 2015. "Egypt's Mahragan: Music of the Masses." Middle East Institute. July 07. Last Retrieved fromhttp://www.mei.edu May 2017

Hakim (2018). "Aandk Nozoulah." Last Retrieved from https://www.youtube.com in June 2018

Hall, S. (1979). "The Great Moving Right Shaw." Marxism Today. Jan. Last Retrieved from http://banmarchive.org.uk in May 2017.

Hall, S. ([1973] 1980): "Encoding/decoding in Television Discourse". In Centre for Contemporary Cultural Studies (Ed.): Culture, Media, Language: Working Papers in Cultural Studies, 1972-79 London: Hutchinson. Last retrieved from http://faculty.georgetown.edu

Jessop, B. (1984). "Authoritarian Populism: Two Nations and Tatcherism." New Left Review. No. 147. Last Retrieved from https://bobjessop.org May 2017. 
Joseph, S. (1993) "Fieldwork and Psychosocial Dynamic of Personhood." Frontiers: A Journal of Women Studies, Vo. 13, No. 3. JSTOR. http://jstor.org Last Retrieved 27/62007

---- (1993)."Gender and Relationality among Arab Families in Lebanon. "Who's East? Whose East? Feminist Studies, Vol.19, No. 3. http://jstor.org Last Retrieved 27/62007

---- (1994). "Brother/Sister Relationships: Connectivity, Love and Power in the Reproduction of Patriarchy in Lebanon." American Ethnologist, Vol.21, No. 1. http://jstor.org Last Retrieved 27/62007

Kilany, M. "Interview conducted by the Researcher" 31 ${ }^{\text {st }}$ of December 2016. Luce, R. (1941) "The American Century." Retrieved from https://dh.oxfordjournals.org

Mason, R. (2012)."David Cameron: Human rights stop Britian Protecting against Terrorism." Telegraph 25 Jan. Last Retrieved from http://telegraph.co.uk. June 2017.

McClintock, A. (1997). "'No Longer in Future Heavens': Gender, Race, and Nationalism". In Anne McClintock, Aamir Mufti, Ella Shohat (Eds.) Dangerous Liaisons: Gender, Nation, \&Postcolonial Perspectives. Minneapolis. London: University of Minnesota Press.

Rakha, Y. (2012). "Jassmi, Take Three." Al-Ahram Weekly. Last Retrieved from http://weekly.ahram.org.eg

Stam, R. (1997) "Multiculturalism and the Neoconservatives." Dangerous Liaisons: Gender Nation, and Postcolonial Perspectives. Ed. Anne McClintock, Aamir Mufti, and Ella Shohat. Minneapolis: Minnesota University Press.

Thomas, D. (1997) "Constructing National and Cultural Identities in SubSaharan Franco-Phone Africa." Not on Any Map: Essays on Postcoloniality and CulturalNationalism. Ed. Stuart Murray. Devon: University of Exterior Press.

Zizek, S (2007). "Tolerance as an Ideological Category". Critical Inquiry (Autumn). Last Retrieved from http//:www.lacan.com in May 2017. 